\title{
A Holistic and Systematic Assessment of Maintenance Approaches in Heritage Sites
}

\author{
ABOBAKR AL-SAKKAF \\ Dept. of Building, Civil, and Environmental Engineering \\ Concordia University, Montréal \\ Dept. of Architecture \& Environmental Planning, College of Engineering \& Petroleum, \\ Hadhramout University, Mukalla, YEMEN \\ SAMER EL-ZAHAB \\ Dept. of Engineering Management, Faculty of Engineering, Kalhat, Koura University \\ of Balamand, Koura, LEBANON \\ ESLAM MOHAMMED ABDELKADER \\ Structural Engineering Department, Faculty of Engineering, Cairo University, Giza, \\ EGYPT \\ GHASAN ALFALAH \\ Dept. of Architecture and Building Science, College of Architecture and Planning King \\ Saud University, Riyadh, SAUDI ARABIA
}

\begin{abstract}
Maintenance approaches of heritage sites (MAHs) on heritage sites have become essential in both the industry and academia as construction projects grow increasingly complex. With a prime goal of increasing its productivity and safety, MAHs research has witnessed tremendous growth over the past three decades. With the increase in research grows the necessity to monitor the research growth of a research topic to identify its trends and gaps, and hence shed the light on research areas that warrant future research attention, there is a lack of systematic literature analysis in MAHs field. To fill this gap, this paper recruited a mixed-review method of scientometric and systematic reviews of research papers on MAHs published from 1990 to 2020 (as of mid of July). Its ultimate objective is to identify current trends, technologies, and techniques in the field of heritage site maintenance and layout their advantages and disadvantages. Additionally, country contributions are highlighted to identify which countries produce the most effective research in the field. Finally, the most cited articles are identified to highlight important topics in the selected time period. As a result, Journal of Destination Marketing \& Management has the highest ranking across the different journals in the area of MAHs based on its number of published articles and their citations. In addition, the publisher Elsevier has the highest number of published articles with 58. Results also demonstrated that the collaboration between Ecuador and Spain accomplished the highest ranking, such that the strength link was estimated to be equal to 3 . Moreover, the highest repetitive keywords were indicators with 20 times and cultural heritage cities with 19 times.
\end{abstract}

Key-Words: - Maintenance, heritage sites, architectural buildings, UNESCO, systematic review

Received: January 13, 2021. Revised: May 20, 2021. Accepted: June 2, 2021. Published: June 18, 2021.

\section{Introduction}

World heritage sites are landmark pieces and strokes of genius that represent the story of humanity and the world we live in. It is essential that world heritage monuments and sites are kept protected and well maintained so that future generations can learn from their stories and be inspired by their wonder $[1,2]$. Based on the UNESCO's classification of World Heritage, we have 3 main categories: (1) Natural, (2)
Cultural, and (3) Underwater Heritage. This article is mainly concerned with cultural heritage which is in turn divided into two main categories: (1) tangible and (2) intangible cultural heritage [3]. Tangible heritage represents the sites, monuments, and structures that were inherited from ancestors and have physical existence today, whereas the intangible cultural heritage represents the traditions and the habits that were inherited from ancestors and are 
passed on throughout the generations $[4,5]$. This article is mainly concerned with the maintenance techniques and approaches that help preserve tangible heritage sites in good conditions so that future generations may learn from them. Today, UNESCO has nearly 1200 world heritage sites inscribed by its state members. Figure 1 demonstrates the distribution of the inscribed sites per country. The graph shows that heritage sites are not localized and accordingly, human history is not localized. To keep those heritage sites serving their purpose, regular maintenance is required. The importance of regular maintenance lies in it being a pragmatic, costeffective, practical, and sustainable approach for the preservation of heritage sites and buildings [6-9].

It is critical to differentiate between the acts of maintenance and repair. The concept of maintenance revolved around the medical idea of "prevention is better than the cure". Therefore, prevention aims to create a set of regular or continuous practices that deter any failure that would require repair. In heritage buildings, maintenance is a set of routine check-ups, building analysis, and tests, which identify any harm before it becomes severe and allows taking small steps to remedy it. All those steps are taken while ensuring the integrity of the site. On the other hand, repair is extensive work to remedy existing or apparent damages. Repairs usually include the blocking of the site for example and are more costly than maintenance $[8,10]$. Due to the importance and benefits of maintenance, it is essential that maintenance be surveyed and mapped.

Based on analysis of previous review articles, it was observed that the literature lacks a research study which can look and synthesize the different current maintenance trends, technologies, and techniques in the field of heritage site maintenance as well as their advantages and disadvantages. In view of the above, this research study aims at the following objectives:

1. Survey the current state of the art in the field of heritage sites maintenance.

2. Provide an overview of the existing trends in the research field.

3. Provide an overview of the technologies and techniques that are used in the field and their advantages and limitations.

\section{Methodology}

In this section, research methodology on maintenance approaches of heritage sites indicated in order to provide future suggestion for researchers to study and evaluate the trends topics interims around the globe of maintenance of heritage sites. In addition, researchers can be conducted more efficient and intensive research, a "mixed review method" is implemented in this research. In Figure 2, expressions a holistic framework of the research methodology. Hence, mixed review methodology comprises both quantitative (scientometric approach) and qualitative review (systematic approach) and therefore delivers the platform for the combination of the advantages of the two approaches. Moreover, in the next step mixed-review method has been acknowledged by many authors due to its ability to eliminate biased conclusion and subjective interpretation while providing an in-depth understanding of domain knowledge and research trends. In the systematic review research, using mixed-methods can be defined as combining the findings of qualitative and quantitative studies within a single systematic review to indicate the same overlapping or complementary review questions [11]. Furthermore, the mixed methods approach to conducting systematic reviews is a process whereby (a) comprehensive syntheses of two or more types of data (e.g. quantitative and qualitative) are conducted and then aggregated into a final, combined synthesis, or (b) qualitative and quantitative data are combined and synthesized in a single primary synthesis [12]. It is also worth mentioning that mixed review method is a widely adopted approach that has been previously implemented in several and diverse applications such as energy efficient related purpose [10], modular construction [13] and etc.

Figure 2 dissects the procedure that was followed to achieve the article's objectives. The first step is to select a scientific database. In the case of this article, the database is "Web of Science". After database selection, a series of searches is conducted around the keyword "Maintenance of heritage sites". Repeating the search using variations of the same keyword is essential to ensure that all related articles are found. All the articles that are collected throughout the search are compiled into a new database that will be MAHs database. The MAHs database serves as the basis for all the work in this article. The MAHs database is then analyzed to determine the trends that are ongoing in the field and shed some light on them, then 15 articles are selected to be further analyzed. The in-depth analysis of the 15 randomly selected articles helps shed the light on some current technologies and their advantages and disadvantages. Also, it helps identify the progression of the research demographics on the level of topics. Additionally, the analysis helps in identifying the direction of the future work in the field based on the needs of the industry and the limitations of certain approaches. 


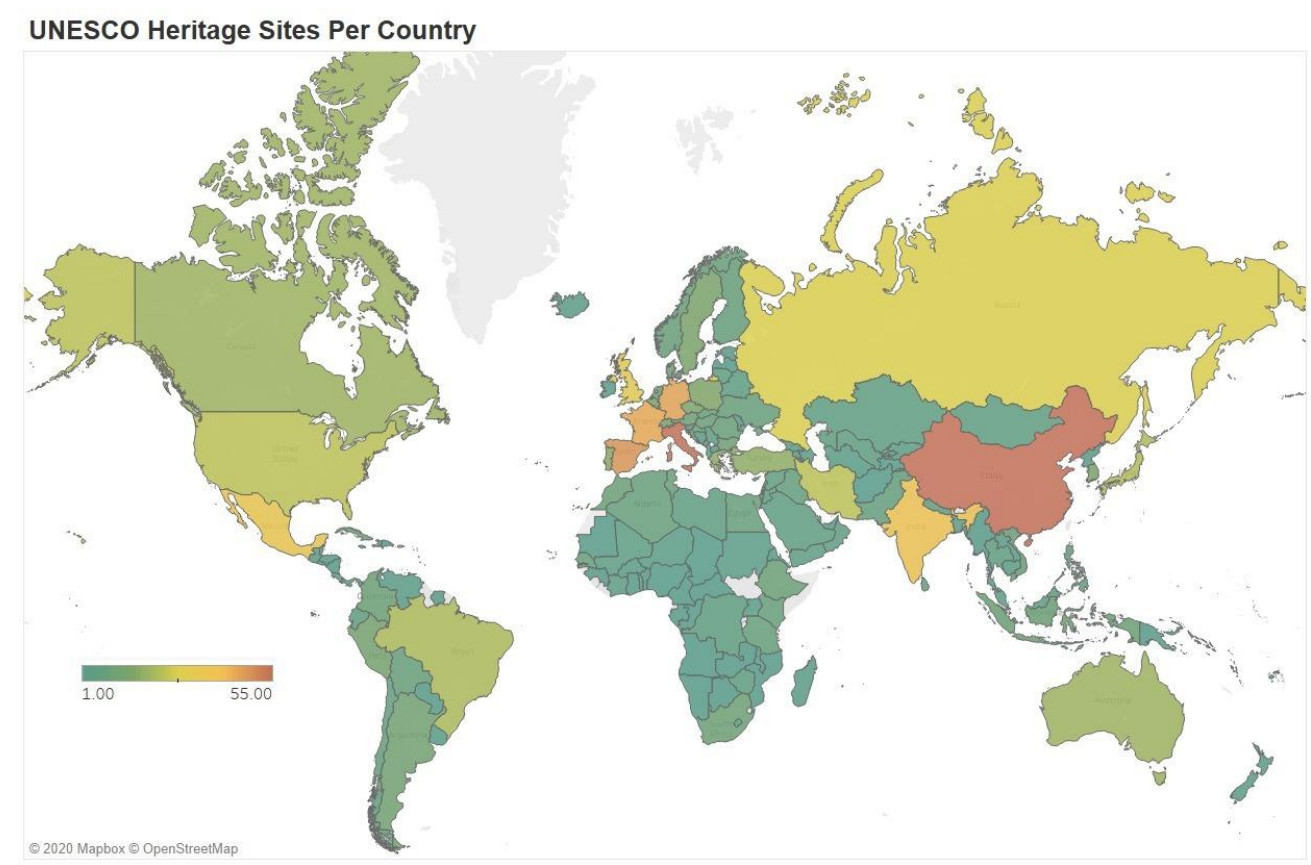

Fig.1: UNESCO heritage sites per country.

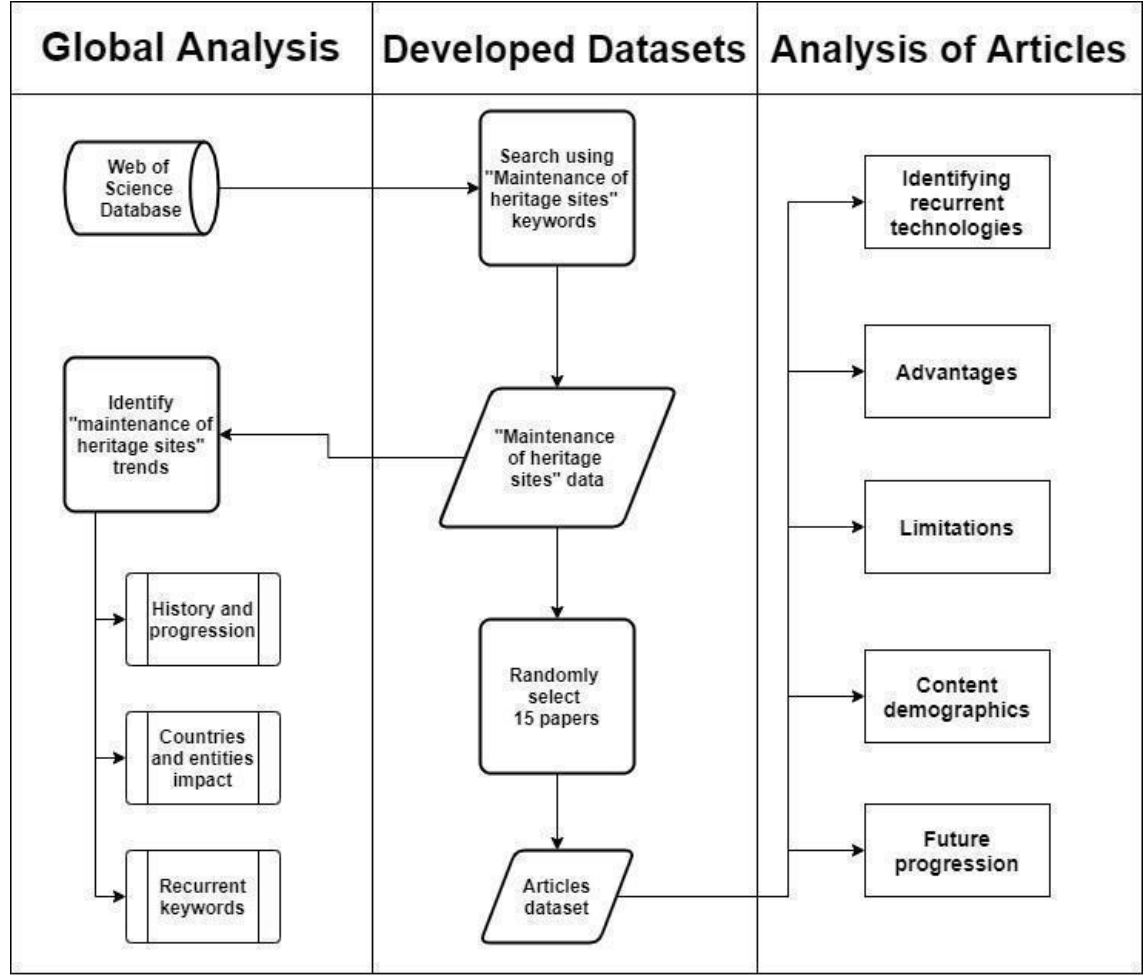

Fig.2: Overall framework of research methodology.

\section{Defining Maintenance of Heritage Sites}

As highlighted in the background, maintenance is the act of preserving the fabric of heritage sites so that they may remain beacons of human history transferred from generation to generation. Poulios [14] classified the acts of maintenance into 5 main activities as follows:

1- Partial replacement of existing material with same material

2- Partial renewal of existing material with different material

3- Total physical renewal 
4- Immersion of physical material

5- Replacement of entire structure

The list starts with the least intense activity and ends with the most demanding and intense activity. Each of those activities has its own sets of advantages, disadvantages, and implications on the repair site [14]. The first technique is the partial replacement of the existing material with the same material. In this technique, materials from the same nature, chemical structures, or even the exact same structure are utilized to repair damages in heritage sites. Such damages may include spalling, deterioration, and cracks. Although uncommon, this practice is utilized in areas where organic materials were used for the construction of heritage sites that are located in areas with hostile environments $[14,15]$.

Partial repair using different material relies on doing repairs by utilizing materials that are assessed to be stronger and better than the original material and do not violate the sacredness or integrity of the heritage site and structure. This practice is common as usually the new material is more effective and much stronger than the old material [16]. Total physical renewal is a common practice mostly due to religious practices where certain parts of sacred sites are renewed in a ritualistic fashion. This also can occur in certain cases where it is safer to provide a total physical renewal to certain areas of the site for safety reasons. This is done while keeping in mind the fabric and rich culture of the site [17]. The immersion of physical material and the replacement of the entire structure in the maintenance of heritage sites usually occur for ritualistic reasons as well. In certain practices, if an element of a heritage site is damaged it needs to be replaced completely [14].

To decide on which maintenance and repair approach to utilize, decision-makers rely on a variety of assessment tools that provide them with insight on the current condition of the site as well as the locations of any defect. A list of the most common techniques has been compiled and recorded in Tables 1,2 and 3. They enlist the name of the technique along with its mode of application, advantages, disadvantages, and references to real-life applications.

Table 1: A summary of common heritage site assessment techniques.

\begin{tabular}{|c|c|c|c|}
\hline $\begin{array}{l}3 D \text { analysis and } \\
\text { digital } \\
\text { photogrammetry }\end{array}$ & $\begin{array}{l}\text { The development and } \\
\text { analysis of computer-based } \\
\text { 3D replicas of heritages } \\
\text { sites and monuments. This } \\
\text { can be done using advanced } \\
\text { tools and sensors. }\end{array}$ & $\begin{array}{ll}\text { - } & \text { Accurate } \\
\text { - } & \text { Portable } \\
\text { - } & \text { Cost efficient } \\
\text { - } & \text { Time efficient } \\
\text { - } & \text { Flexible }\end{array}$ & $\begin{array}{l}\text { - } \begin{array}{l}\text { Requires further } \\
\text { development }\end{array} \\
\text { - } \\
\text { Not widely } \\
\text { available or } \\
\text { used }\end{array}$ \\
\hline
\end{tabular}

[17-21] (Al-Kheder et al. 2009; Remondino and Rizzi 2010; Dore and Murphy 2012; Jahanshahi et al. 2013; Galantucci and Fatiguso 2019)

\begin{tabular}{|c|c|c|c|c|}
\hline $\begin{array}{l}\text { Atomic } \\
\text { absorption } \\
\text { spectrometry }\end{array}$ & $\begin{array}{l}\text { A device sends beams of } \\
\text { light onto a sample (the } \\
\text { specific form and origin of } \\
\text { the light depends on the } \\
\text { manufacturer, usually } \\
\text { hollow cathode lamps). } \\
\text { Behind the sample will be a } \\
\text { reader that determines how } \\
\text { much of the light was } \\
\text { absorbed by the sample. }\end{array}$ & 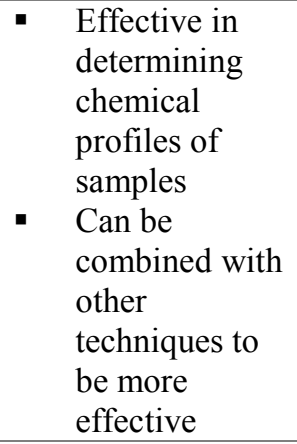 & $\begin{array}{ll}\text { - } & \text { Subject to } \\
\text { interference } \\
\text { - } & \text { Interacts with a } \\
\text { limited number } \\
\text { of elements in } \\
\text { heritage sites } \\
\text { - } \quad \text { Requires taking } \\
\text { a sample from } \\
\text { the site which } \\
\text { may not be } \\
\text { viable }\end{array}$ & $\begin{array}{l}{[22,23] \text { (Filho et }} \\
\text { al. 2011; } \\
\text { Pinheiro et al. } \\
\text { 2019) }\end{array}$ \\
\hline $\begin{array}{l}\text { Colorimetric } \\
\text { evaluation }\end{array}$ & $\begin{array}{l}\text { A sample is collected and } \\
\text { analyzed with a reactive } \\
\text { coloring chemical to } \\
\text { determine the chemical } \\
\text { composition of the sample. }\end{array}$ & $\begin{array}{l}\text { Effective when } \\
\text { dealing with } \\
\text { limestone and } \\
\text { plasterwork. } \\
\text { - Cost effective } \\
\text { - } \quad \text { Portable }\end{array}$ & $\begin{array}{l}\text { Requires the } \\
\text { collection of a } \\
\text { sample which } \\
\text { may not always } \\
\text { be viable } \\
\text { - } \begin{array}{l}\text { Does not work } \\
\text { effectively with }\end{array}\end{array}$ & $\begin{array}{l}{[24,25] \text { (Comite et }} \\
\text { al. } 2017 \text {; } \\
\text { Collado-Montero } \\
\text { et al. 2019) }\end{array}$ \\
\hline
\end{tabular}




\begin{tabular}{|c|c|c|c|c|}
\hline & & & $\begin{array}{l}\text { other } \\
\text { construction } \\
\text { materials }\end{array}$ & \\
\hline $\begin{array}{l}3 D \text { analysis and } \\
\text { digital } \\
\text { photogrammetry }\end{array}$ & $\begin{array}{l}\text { The development and } \\
\text { analysis of computer-based } \\
\text { 3D replicas of heritages } \\
\text { sites and monuments. This } \\
\text { can be done using advanced } \\
\text { tools and sensors. }\end{array}$ & $\begin{array}{ll}\text { - } & \text { Accurate } \\
\text { - } & \text { Portable } \\
\text { - } & \text { Cost efficient } \\
\text { - } & \text { Time efficient } \\
\text { - } & \text { Flexible }\end{array}$ & $\begin{array}{l}\text { - } \begin{array}{l}\text { Requires further } \\
\text { development }\end{array} \\
\text { - } \\
\text { Not widely } \\
\text { available or } \\
\text { used }\end{array}$ & $\begin{array}{l}\text { [17-21] (Al-Kheder } \\
\text { et al. 2009; } \\
\text { Remondino and } \\
\text { Rizzi 2010; Dore } \\
\text { and Murphy 2012; } \\
\text { Jahanshahi et al. } \\
\text { 2013; Galantucci } \\
\text { and Fatiguso 2019) }\end{array}$ \\
\hline
\end{tabular}

Table 2: A summary of common heritage site assessment techniques (Cont'd).

\begin{tabular}{|c|c|c|c|c|}
\hline $\begin{array}{l}\text { Eddy current } \\
\text { thermography }\end{array}$ & $\begin{array}{l}\text { Eddy currents thermography relies } \\
\text { on creating eddy current pulse via } \\
\text { induction that would heat the area } \\
\text { that is being tested. After the tested } \\
\text { region is heated thermography is } \\
\text { applied to detect any defects. }\end{array}$ & $\begin{array}{l}\text { - } \text { Non-destructive } \\
\text { - Can detect } \\
\text { surface and } \\
\text { subsurface } \\
\text { defects } \\
\text { Accurate }\end{array}$ & $\begin{array}{l}\text { Only works on } \\
\text { materials that } \\
\text { allow induction }\end{array}$ & $\begin{array}{l}{[26,27]} \\
\text { (Arndt } \\
\text { 2010; } \\
\text { De Capua } \\
\text { et al. 2018) }\end{array}$ \\
\hline $\begin{array}{l}\text { Fourier } \\
\text { transform } \\
\text { infrared test }\end{array}$ & $\begin{array}{l}\text { A device emits infrared radiation } \\
\text { through a given sample from the } \\
\text { material to be tested. Depending on } \\
\text { the components a portion of the } \\
\text { radiation will be absorbed. The } \\
\text { absorbed radiation will be converted } \\
\text { to energy. This energy will create a } \\
\text { vibrational signal that can be } \\
\text { analyzed to determine the material } \\
\text { footprint. }\end{array}$ & $\begin{array}{ll}\text { - } & \text { Non-destructive } \\
\text { - } & \text { Highly sensitive } \\
\text { - } & \text { Specific } \\
\text { - } & \text { Helps identify } \\
\text { material } \\
\text { composition } \\
\text { (organic, } \\
\text { inorganic, } \\
\text { polymer) }\end{array}$ & 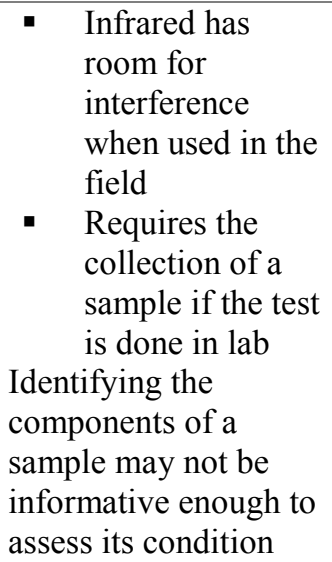 & $\begin{array}{l}\text { [28-30] } \\
\text { (Castillo et } \\
\text { al. 2012; } \\
\text { Fierascu et } \\
\text { al. 2019; } \\
\text { Rosi et al. } \\
\text { 2019) }\end{array}$ \\
\hline $\begin{array}{l}\text { Nuclear } \\
\text { magnetic } \\
\text { resonance }\end{array}$ & $\begin{array}{l}\text { A collected sample would be placed } \\
\text { in a magnetic field. Then, the } \\
\text { sample is subjected to nuclear } \\
\text { magnetic resonance by means of } \\
\text { radio waves until the nuclei within } \\
\text { the sample reach a resonance state. } \\
\text { This produces a field spectrum that } \\
\text { can be analyzed to determine the } \\
\text { composition of the sample. }\end{array}$ & $\begin{array}{l}\text { - } \text { Non-destructive } \\
\text { - Highly sensitive } \\
\text { - } \text { Specific } \\
\text { - Helps identify } \\
\text { material } \\
\text { composition } \\
\text { (organic, } \\
\text { inorganic, } \\
\text { polymer) }\end{array}$ & $\begin{array}{l}\text { Require the } \\
\text { collection of a } \\
\text { sample which } \\
\text { may not always } \\
\text { be viable } \\
\text { Identifying the } \\
\text { components of a } \\
\text { sample may not be } \\
\text { informative enough to } \\
\text { assess its condition }\end{array}$ & $\begin{array}{l}{[31,32]} \\
\text { (Capitani et } \\
\text { al. 2012; } \\
\text { Proietti et } \\
\text { al. 2014) }\end{array}$ \\
\hline
\end{tabular}

Table 3: A summary of common heritage site assessment techniques (Cont'd-2).

\begin{tabular}{|c|c|c|c|c|}
\hline $\begin{array}{l}\text { Scanning } \\
\text { electron } \\
\text { microscopy } \\
\text { and } \\
\text { dispersive } X \text { - } \\
\text { ray } \\
\text { spectroscopy }\end{array}$ & $\begin{array}{l}\text { An electron beam is generated by the } \\
\text { device and is directed towards the } \\
\text { surface of the sample that is being } \\
\text { analyzed. The collision creates } \\
\text { secondary electrons from the sample } \\
\text { while some of the applied electrons } \\
\text { scatter around the device. Those } \\
\text { interactions are measured by a detector } \\
\text { to develop an X-ray electromagnetic } \\
\text { spectrum. The spectrum can be analyzed }\end{array}$ & $\begin{array}{ll}\text { - } & \text { Non- } \\
\text { destructive } \\
\text { - } & \text { Highly } \\
\text { - } & \text { Sensitive } \\
\text { - } & \text { Helpsific identify } \\
\text { material } \\
\text { composition } \\
\text { (organic, }\end{array}$ & $\begin{array}{l}\text { Works only } \\
\text { on a surface } \\
\text { level thus no } \\
\text { deep insights } \\
\text { can be } \\
\text { provided } \\
\text { May require } \\
\text { sampling in certain } \\
\text { scenarios }\end{array}$ & $\begin{array}{l}{[33-35]} \\
\text { (Camm et } \\
\text { al. 2003; } \\
\text { Melcher and } \\
\text { Schreiner } \\
2005 \text {; } \\
\text { Vasiliev et } \\
\text { al. 2016) }\end{array}$ \\
\hline
\end{tabular}




\begin{tabular}{|c|c|c|c|c|}
\hline & $\begin{array}{l}\text { to determine the surface elemental } \\
\text { concentrations. }\end{array}$ & $\begin{array}{l}\text { inorganic, } \\
\text { polymer) }\end{array}$ & & \\
\hline $\begin{array}{l}\text { Ultrasonic } \\
\text { testing }\end{array}$ & $\begin{array}{l}\text { An emitter and a receiver are placed on } \\
\text { opposite ends of the investigated } \\
\text { element. The emitter sends ultrasonic } \\
\text { waves throughout the body that are } \\
\text { collected by the receiver. The travel time } \\
\text { is recorded. With data such as gap } \\
\text { distance, the internal structure of the } \\
\text { element is constructed. }\end{array}$ & 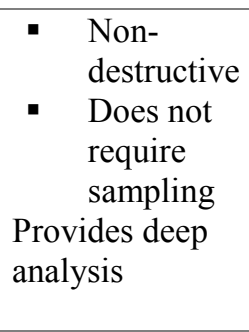 & $\begin{array}{l}\text { Might be difficult } \\
\text { to assess in } \\
\text { structures of } \\
\text { unknown material } \\
\text { composition or } \\
\text { composite structure }\end{array}$ & $\begin{array}{l}{[36-38]} \\
\text { (Ruedrich et } \\
\text { al. 2013; } \\
\text { Akoglu et } \\
\text { al. 2020; } \\
\text { Rucka et al. } \\
\text { 2020) }\end{array}$ \\
\hline
\end{tabular}

\section{Results and Discussion of Scientometric Review of MAHs}

\subsection{Network Analysis of Journals Contributing to MAHs}

Analysis of the journals which publish articles related to MAHs is a necessary step in the scientometric review to identify the high impact journals, map its network, and hence guide the researchers to the key journals in this field. The identification of academic journals containing papers on MAHs in construction was undertaken using the Web of Science. Journal of Destination Marketing \& Management, AceArchitecture City and Environment, Anais Brasileiros De Estudos Turisticos-Abet, Boletin De La Asociacion De Geografos Espanoles, Cuadernos De Turismo, Historic Environment-Policy \& Practice, International Journal of Architectural Heritage, Journal of Cultural Heritage Management And Sustainable Development, Pasos-Revista De Turismo Y Patrimonio Cultural, Annals of Tourism Research were recognized as the top ten (10) journals among the retrieved results. Table 4 reports the ranking of the retrieved journals. All these journals have their respective virtual libraries including Elsevier, ASCE, Wiley Online, Canadian Science Publishing and Emerald Insight which are among the leading virtual libraries in construction engineering research. Table 4 also indicates the top 10 Journals on MAHs research identified from the search for the period under study. For instance, Sustainability journal contains four researches related to MAHs with 13 citations, and Tourism Management journal contains three researches related to MAHs with 147 citations.

Table 4: Search History - Overview of Results.

\begin{tabular}{lc}
\hline \multicolumn{1}{c}{ Selected Journals } & $\begin{array}{c}\text { No. of papers } \\
\text { from search }\end{array}$ \\
\hline $\begin{array}{l}\text { Destination Marketing \& } \\
\text { Management }\end{array}$ & 4 \\
\hline
\end{tabular}

\begin{tabular}{ll}
\hline $\begin{array}{l}\text { Ace-Architecture City and } \\
\text { Environment }\end{array}$ & 3 \\
\hline $\begin{array}{l}\text { Anais Brasilerios De Estudos } \\
\text { Turisticos-Abet }\end{array}$ & 3 \\
\hline $\begin{array}{l}\text { Boletin De La Asociacion De } \\
\text { Geografos Espanoles }\end{array}$ & 3 \\
\hline $\begin{array}{l}\text { Cuadernos De Turismo } \\
\text { Historic Environment-Policy \& } \\
\text { Practice }\end{array}$ & 3 \\
\hline $\begin{array}{l}\text { Int. J. of Architectural Heritage } \\
\text { J. of Cultural Heritage } \\
\text { management and Sustainable } \\
\text { Development }\end{array}$ & 3 \\
\hline $\begin{array}{l}\text { Pasos-Revista De Tuismo Y } \\
\text { Patrimonio Cultural }\end{array}$ & 3 \\
\hline Annals of Tourism Research & 3 \\
\hline \multicolumn{1}{c}{ Total } & $\mathbf{3 0}$ \\
\hline
\end{tabular}

\subsection{Assessment of Contributions}

Researches and academic institutions contribute to the industrial practises through different ways, the most significant being the publication of their research papers. Furthermore, the number of research contributions in a country signifies its progress on the subject in that country [39]. Therefore, identifying active contributors to a field is a solid approach to understanding the general research trend of that particular field [40]. As a result, researchers can make use of this approach to track the contributions of previous researchers and utilize the results for further improvement on previous works by other researchers. Accordingly, this approach was used to provide insights on the current state of industrial developments in different countries related to MAHs as well as research contributions of researchers from their respective countries and institutions are presented and discussed in the subsequent session of this paper.

The study aims at highlighting the contributions of countries, institutions and researchers to MAHs research. Also, assessing the contributions of 
researchers, institutions and countries have been of interest to several researchers [41-44]. Hence, this study explored the contributions of countries, institutions and researchers to MAHs research during the studied period. The score matrix provided in Table 5 was applied in the calculation of the contributions of countries, institutions and researchers. In order to obtain the total contribution score for a particular country and institution, the individual scores of all authors from the same country and institution are summed up. For example, if author ' $Y$ ', from a particular country, has the first and second authorship, respectively, in two different papers, in which there are just two authors, according to the score matrix, author ' $\mathrm{Y}$ ' is scored one point $(0.6 \& 0.8)$ each for his or her country and institution. The approach is utilized for the sake of computing the contributions of countries and institutions of the selected papers. For example, Sustainability journal contains four researches related to MAHs with 13 citations, and Tourism Management journal contains three researches related to MAHs with 147 citations, so the total link strength for the second journal is higher from the first one as shown on Table 5. Similarly, historic environment-policy \& practice journal has 3 papers with 8 citations. As a result, journal of destination marketing $\&$ management has the highest ranking across the different journals in the area of MAHs based on its number of published articles and their citations. In addition, the publisher Elsevier has the highest number of published articles with 58. Although, results also determined that the collaboration between Ecuador and Spain accomplished the highest ranking, such that the strength link was valued to be equal to 3 . Besides, the highest repetitive keywords were indicators with 20 times and cultural heritage cities with 19 times as shown in Table 5.

Table 5: Search History - Overview of Results.

\begin{tabular}{lccc}
\hline \multicolumn{1}{c}{ Source } & Papers & Citations & Link Strength \\
\hline Sustainability & 9 & 13 & 31 \\
\hline Destination Marketing \& Management & 4 & 23 & 99 \\
\hline Ace-Architecture City and Environment & 3 & 1 & 12 \\
\hline Anais Brasilerios De Estudos Turisticos-Abet & 3 & 2 & 10 \\
\hline Boletin De La Asociacion De Geografos Espanoles & 3 & 4 & 32 \\
\hline Cuadernos De Turismo & 3 & 0 & 22 \\
\hline Historic Environment-Policy \& Practice & 3 & 8 & 9 \\
\hline Int. J. of Architectural Heritage & 3 & 3 & 1 \\
\hline J. of Cultural Heritage management and Sustainable Development & 3 & 5 & 13 \\
\hline Pasos-Revista De Tuismo Y Patrimonio Cultural & 3 & 7 & 30 \\
\hline Tourism Management & 3 & 147 & 72 \\
\hline Annals of Tourism Research & 2 & 256 & 6 \\
\hline Int. J. of Contemporary Hospitality Management & 2 & 45 & 78 \\
\hline Sustainable Cities and Society & 2 & 5 & 3 \\
\hline Tourism Geographies & 2 & 12 & 12 \\
\hline
\end{tabular}

\subsection{Annual Maintenance Approaches}

Figure 3 below, depicts information pertinent to the number of MAHs research publications per year over the last three decades. It has been observed that research on MAHs in the construction field has received considerable attention from the research community. For the first two decades, between 1990 and 2010, there were only papers published on MAHs. As for the third decade (2011-2020), research on MAHs has fluctuated between the period from 2011 to 2020. Moreover, an all-time peak of 22 publications was obtained in 2019. Such an increase in the number of publications is not unexpected as the need for increasing the preservation of heritage sites due to the frequent neglect and damage to which they are exposed. 


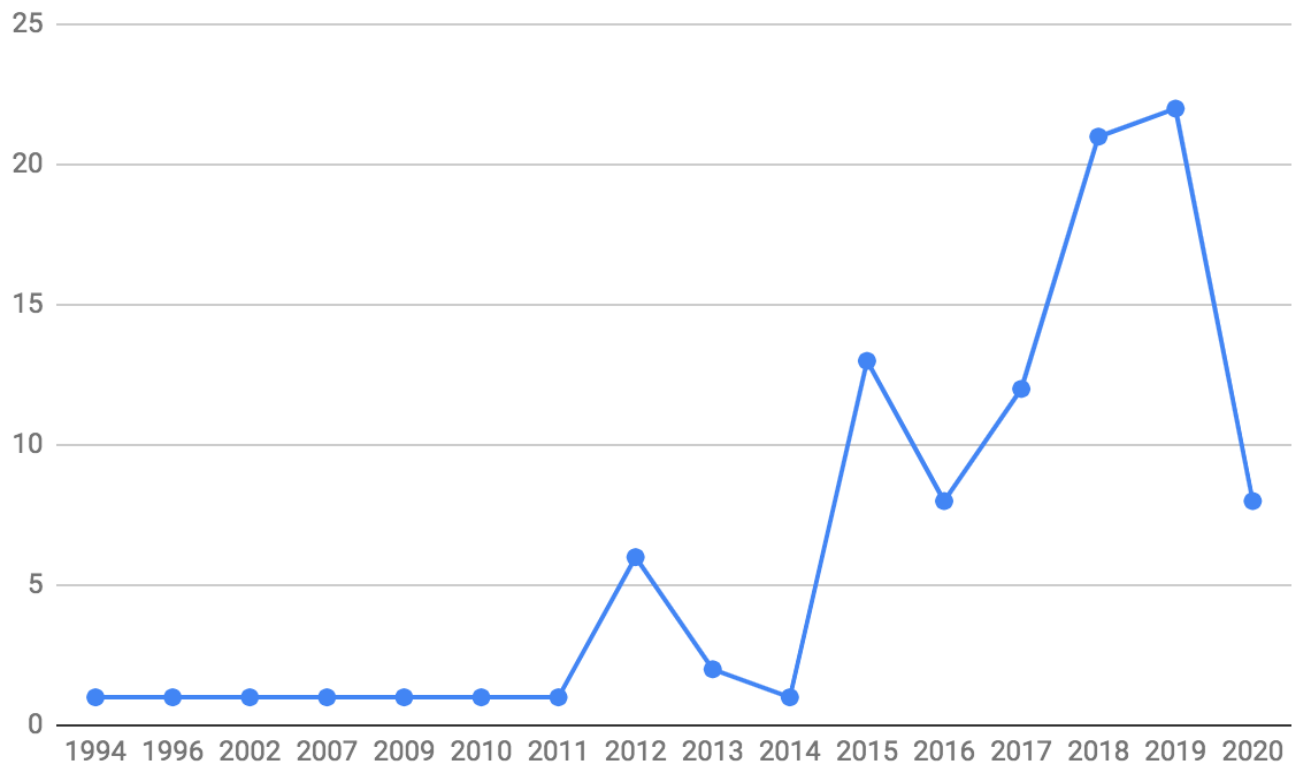

Fig.3: Annual maintenance approaches of heritage sites (MAHs) research publication from 1990 to 2020.

\subsection{Assessment of Contributions}

Figure 4 shows that the main journals in the field of MAHs are (1) Sustainability MDPI, (2) ACE: Architecture, City, and Environment journal, (3) Journal of destination marketing and management, and (4) the international journal of contemporary hospitality management. A view of the scopes of those journals provides a larger view of the topics at hand. Sustainability aims to be a form for sustainability-based research and sustainable development including the cultural heritage. Accordingly, the journal publishes articles on the sustainable development of cultural heritage. ACE focuses on the architectural and environmental aspects of heritage development. Accordingly, their research on maintenance follows those topics as well. Journal of destination marketing and management focuses on maintenance research that would help tourist destinations (heritage sites included) be more attractive and appealing to visitors. Similarly, the international journal of contemporary hospitality management targets the maintenance and management of heritage sites from a touristic point of view. Based on what proceeded, there appears to be a need for more dedicated venues that focus on the maintenance of heritage sites from a pure scientific and historical perspective.

Figure 5 provides information about the main keywords related to the subject. For example, rehabilitation, built heritage, conservation, sustainability, participation, word heritage, heritage cities, historic urban landscape, tourism, design.
Also, Figure 5 provides information about the main keywords related to the subject. For example, rehabilitation, built heritage, conservation, sustainability, participation, word heritage, heritage cities, historic urban landscape, tourism, design. From the results reported in Table 6, the subject of MAHs has been undertaken in many countries, making it a topic of global concern. However, the major part of the research was conducted in Spain, Ecuador, and Mexico which had the most significant number of institutions publishing papers on MAHs research.

Table 6: Top 10 Publishers in MAHs research.

\section{To 9 Publishers}

\begin{tabular}{lc}
\hline Elsevier & 58 \\
\hline MDPI & 14 \\
\hline Taylor \& Francis Ltd. & 10 \\
\hline Taylor \& Francis Inc. & 7 \\
\hline MDPI AG & 5 \\
\hline Hindawi Ltd. & 4 \\
\hline Emerlad & 2 \\
\hline Penerbit UTM Press & 2 \\
\hline Assoc Chemical Eng. & 1 \\
\hline IGI & 3
\end{tabular}




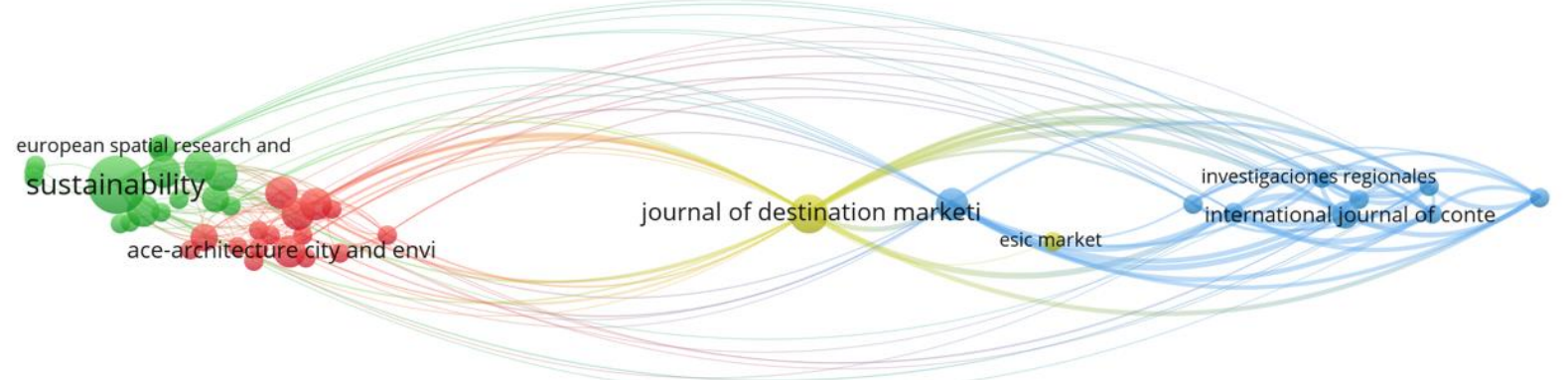

Fig.4: Network of high impact journals on MAHs.

rehabilitation

built heritage

\& VOSvien

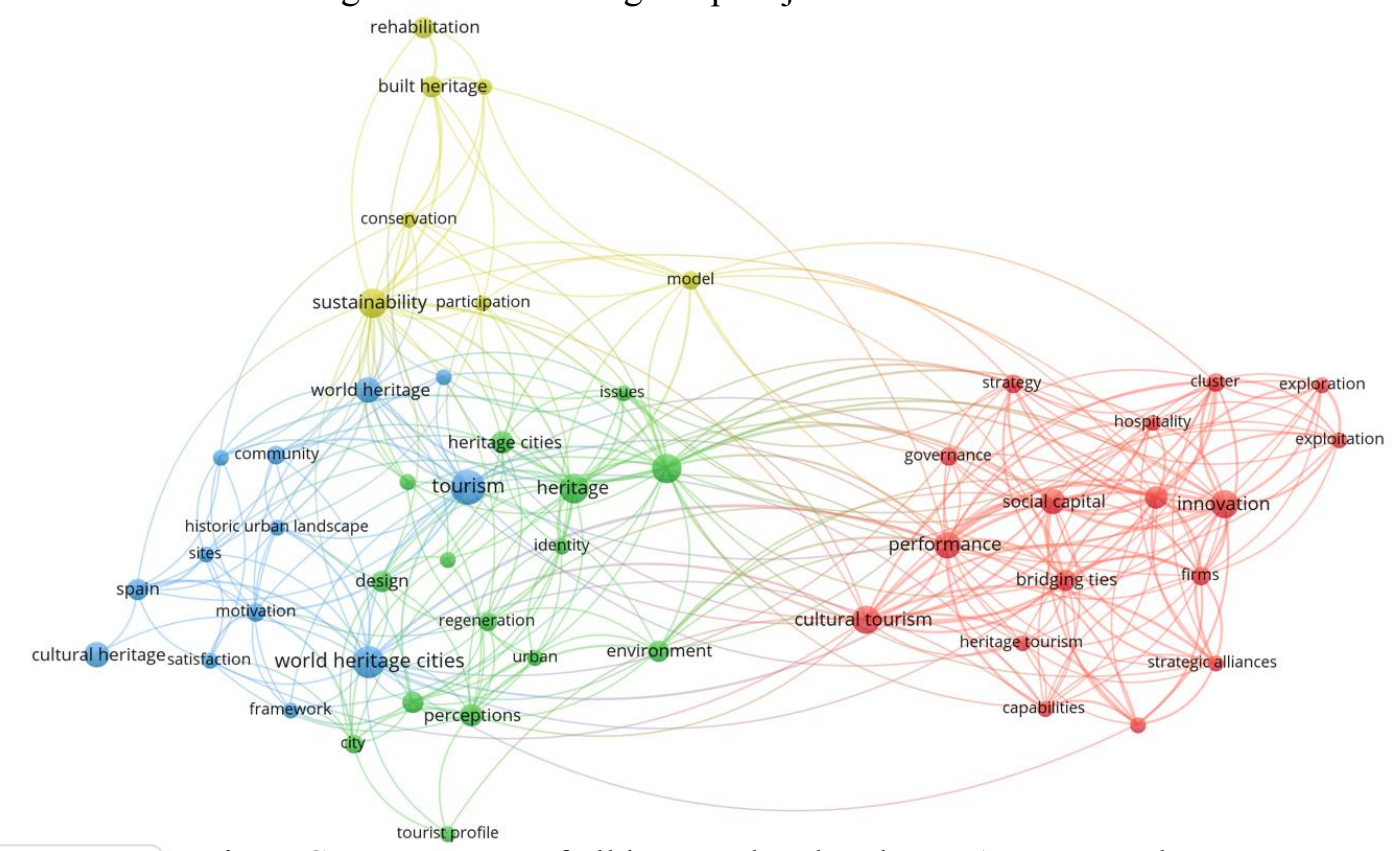

B vosviewer Fig.5: Co-occurrence of all keywords related to MAHs research.

In order to determine the relationship among the various countries, VOSviewer software was utilized to determine the most influential countries and the collaborations between them, which is challenging to derive using the score matrix. The type of analysis selected was "co-authorship"; the unit of analysis was "countries", and the counting method employed was "fractional counting". Moreover, the minimum number of documents of a country and the minimum number of citations from a country were both set at five. Eleven countries met these thresholds and were included in the resultant network which is visualized in Figure 6. The most influential countries were identified in the network by using weighted degree values. Nodes were recoloured and resized based upon their weighted degree values, with larger nodes and lighter shades indicating higher weighted degrees values. Figure 7 presents the distribution of citations per country. 
Table 7: Score matrix for multi-authored papers.

\begin{tabular}{ccccccccc}
\hline & \multicolumn{8}{c}{ Order of specific author } \\
\cline { 2 - 9 } No. of authors & 1 & 2 & 3 & 4 & 5 & 6 & 7 & 8 \\
\hline $\mathbf{1}$ & 1.00 & & & & & & & \\
\hline $\mathbf{2}$ & 0.67 & 1.00 & & & & & & \\
\hline $\mathbf{3}$ & 0.44 & 0.67 & 1.00 & & & & & \\
\hline $\mathbf{4}$ & 0.30 & 0.44 & 0.67 & 1.00 & & & & \\
\hline $\mathbf{5}$ & 0.20 & 0.30 & 0.44 & 0.67 & 1.00 & & & \\
\hline $\mathbf{6}$ & 0.13 & 0.20 & 0.30 & 0.44 & 0.67 & 1.00 & & \\
\hline $\mathbf{7}$ & 0.09 & 0.13 & 0.20 & 0.30 & 0.44 & 0.67 & 1.00 & \\
\hline $\mathbf{8}$ & 0.06 & 0.09 & 0.13 & 0.20 & 0.30 & 0.44 & 0.67 & 1.00 \\
\hline
\end{tabular}

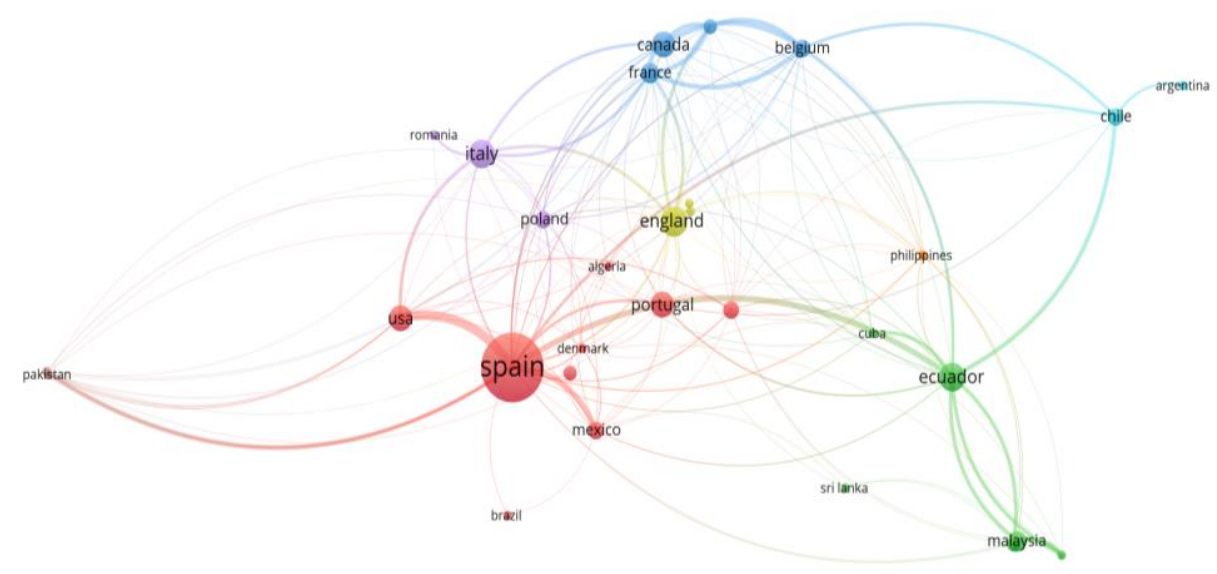

The fundamental purpose of this analysis was to ascertain the various collaborations among countries with regards to MAHs research. Table 7 presents the link strength in terms of collaborations among the top countries publishing MAHs research. Ecuador and Spain had the highest collaboration strength link of 3 . These results show that research collaboration on MAHs exists between these countries, indicating an exchange of information. Despite that the United States had the most significant contribution in MAHs research, its collaboration with other contributed countries such as Spain, China and Italy is not satisfactory. This may be a lack of cross-country comparative studies in the existing MAHs research, and hence collaborations among these countries should be encouraged to produce more diverse research in MAHs.
Table 8: Top Researchers in MAHs Research.

\begin{tabular}{lll}
\hline Researcher & Papers & Score \% \\
\hline Martinez-Perez, A & 10 & 3.56 \\
\hline Garcia-Villaverde, PM & 9 & 3.32 \\
\hline Elche, D & 8 & 3.05 \\
\hline Lopez-Guzman, T & 3 & 1.18 \\
\hline Bajgier-Kowalska, M & 2 & 0.80 \\
\hline Caldeira, AT & 2 & 0.80 \\
\hline Candeias, A & 2 & 0.81 \\
\hline Carrillo-Hidalgo, I & 2 & 0.82 \\
\hline Del Rio, M & 2 & 0.82 \\
\hline Galvez, JCP & 2 & 0.83
\end{tabular}

\section{Analysis of Selected Papers}

The production of knowledge per country over the analyzed time span shows that the top three countries based on the number of articles published in the Web 
of Science database are Spain, the United Kingdom, and Italy. The list of countries is further mapped out in Figure 8. The top 3 countries share one interesting trait, i.e. all three countries possess a wealth of heritage sites and historical landmarks. Spain possesses $4 \%$ of all world heritage sites inscribed by UNESCO, the UK has $2.67 \%$, and Italy has $4.59 \%$ [45]. It is plausible to argue that the abundance of research materials in these countries allows the proliferation of research that is related to the field. In Table 8, 9 and 10, it is equally important to highlight that the work and research conducted to preserve heritage sites is the duty and responsibility of all nations as it is work performed to preserve the history of humanity.

Table 9: Strength Links among the 12 Top Countries Publishing MAHs Papers.

\begin{tabular}{lc}
\hline \multicolumn{1}{c}{ Countries } & Link Strength \\
\hline Ecuador and Spain & 3 \\
\hline Chile and Ecuador & 2 \\
\hline Mexico and Spain & 2 \\
\hline Belgium and Canada & 1 \\
\hline Belgium and Chile & 1 \\
\hline Belgium and Ecuador & 1 \\
\hline Belgium and France & 1 \\
\hline Belgium and Germany & 1 \\
\hline Canada and France & 1 \\
\hline Canada and Germany & 1 \\
\hline Canada and Italy & 1 \\
\hline Chile and Spain & 1 \\
\hline
\end{tabular}

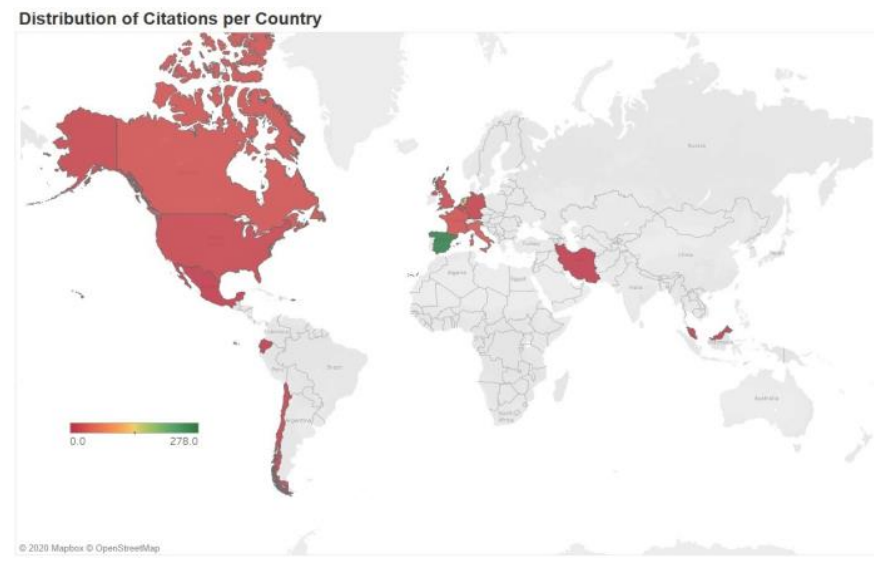

Fig.7: Distribution of citations per country.

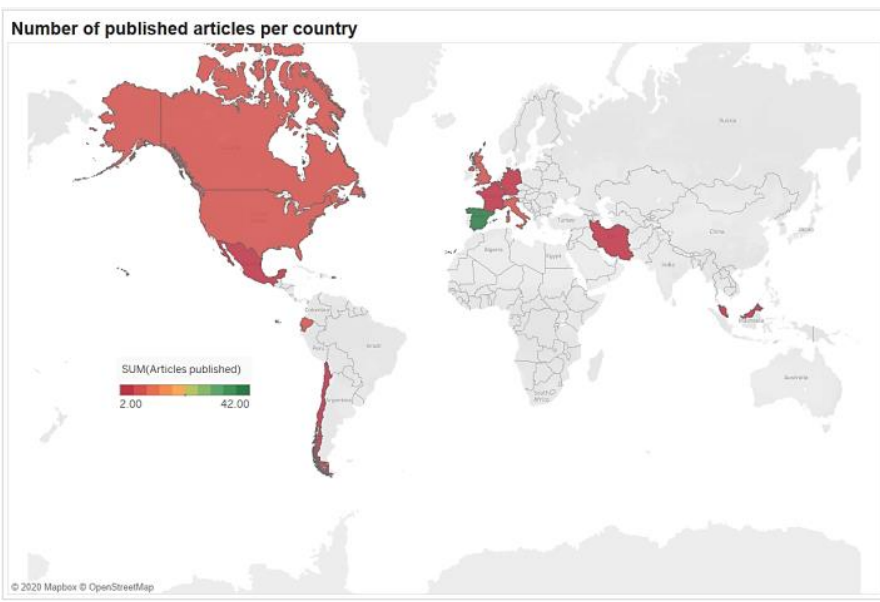

Fig.8: Distribution of citations per country.

Table 10: Keyword and strength link to MAHs research.

\begin{tabular}{lc}
\hline \multicolumn{1}{c}{ Keyword } & Link Strength \\
\hline Indicators & 20 \\
\hline Cultural Heritage Cities & 19 \\
\hline Satisfaction & 19 \\
\hline World Heritage & 19 \\
\hline Stakeholers & 16 \\
\hline Sustainable Development & 16 \\
\hline Built Heritage & 13 \\
\hline Historic Tourism & 13 \\
\hline Historic City & 10 \\
\hline Cluster & 9 \\
\hline Historic Urban Landscape & 9 \\
\hline Tourism & 9 \\
\hline
\end{tabular}




\section{Technologies and Approaches Overview}

Several researches have been showed to develop effective maintenance management systems for large public organizations. These comprise the following studies:

Howard [46] and Al-Sakkaf et al. [47] stated on the practices and actions for preventative maintenance for school buildings. These studies stated further that "without these practices, a preventive maintenance program may not fulfill its goals". In addition, the best practices comprise "inventory building components and assess their conditions, build the capacity for ranking maintenance projects and evaluating their costs, plan purposefully for preventive maintenance in the long-and-short-term, structure a framework for operating a preventive maintenance program, use tools to optimize the preventive maintenance program, advance the competence of maintenance workers and managers, and involve appropriate maintenance personnel in decision-making and in communicating buildings' needs". This research has not implied how the effectiveness of these best practices can be adjudicated to preserve the proposed use of heritage buildings.

According to the World Heritage Sites (2011) recommended average life expectancy for equipment and building components which include building enclosures, roofing systems, windows and exterior doors, interior construction, plumbing systems, elevators, heating, ventilation and air conditioning, electrical systems, site work and utilities. For example, they suggested the average life expectation for all types of elevators is $15-20$ years. This initiative can be useful as an input in the process of developing a maintenance management standard of heritage buildings.

Legat and Jurča [48] determined how a general quality management system according to ISO 9000: 2000 is implemented in maintenance processes. Moreover, the authors presented many factors for asset requirements on maintenance and achievement of defined maintenance quality characteristics. These factors include basic requirements for maintenance of assets, organizational structure, procedures and processes, maintenance financing, internal and external maintenance (outsourcing) and Information system and maintenance documentation. Nevertheless, Legat and Jurča have been failed short of developing a standard for maintenance management that can be applied in heritage maintenance domain.

Levitt [49] indicated that maintenance management as a quality assurance process by projecting the ISO 9001: 2000 standard on the maintenance management activities. Levitt stated that "most modern maintenance management activities are not linked to quality management systems". Conversely, Levitt has not presented any quality criteria which can be clearly used for developing maintenance management standards. Lam [50] listed several quality criteria such as high reliability of services, quick response to maintenance problems, on-going improvement and compliance with statutory requirements. Although these quality criteria can be expended in developing maintenance management standards of heritage sites.

Iwarere and Lawal [51] presented some factors that can be considering the adverse consequences of an effective maintenance in public facilities, these factors include "excessive machine breakdown, disproportionate investment in spare parts and maintenance materials, poor utilization of staff, low quality of service, abnormal overtime cost, irregular operating time, shortened life span of facilities, loss in production output, frequent machine breakdown". Ali and Mohamad [52] evaluated the existing facilities maintenance management in public hospitals in Malaysia. Their assessed based on five elements namely: (1) Leadership; (2) Policies, plan and procedures; (3) Training and orientation; (4) Monitoring and supervision; and (5) Service performance. Every one of these elements has many subsystems or factors, for example when they evaluate that service performance that provided by contractors, they have developed 12 factors which include: (1) Asset registers management; (2) Infrastructures support ; (3) Spares management; (4) PPM task lists; (5) PPM scheduling; (6) Safety management; (7) Statutory compliance; (8) Plant room management; (9) Maintenance performance; (10) Equipment history; (11) Quality assurance and (12) Competency training.

Cholasuke et al. [53] clarified the status of maintenance management in UK manufacturing organizations. They conducted a survey which divided into two parts: General information and Maintenance measurement. They have developed ten elements for maintenance performance measures which encompass: (1) Maintenance effectiveness; (2) Maintenance policy and organization, (3) Maintenance approach, (4) Task planning and scheduling, (5) Information management and CMMs; (6) Spare part management; (7) Human resource management, (8) Contracting out 
maintenance, (9) Financial aspect, and (10) Continuous improvement.

Shamsuddin et al. [54] listed several quality criteria to implement total quality management (TQM). These criteria comprise maintaining basic equipment condition, prevention of human error, detection of error at the source, caring for cleanliness and tidy working environment, worker skill development for self-maintenance, maintaining operating standards, improving design weakness, established repair methods, prediction of deterioration, looking to shop floor as the source of ideas, empowerment of workers, and Formation of small group activities. Alsyouf [55] aimed that analyzing the maintenance practices which are implemented in Swedish industry. Al-Sakkaf et al. [56] indicated several quality criteria that should be considered to analyze maintenance practices. López [57] stated that the most important of these criteria include Implementation of computerized maintenance management systems (CMMS), recording and analyzing failure data to improve causes of equipment failure, monitoring the rate of poor quality, monitoring spare parts and keeping it at the level low, delivering inventory between machines, comparing maintenance tasks based on statistical modeling and condition monitoring of heritage buildings.

\section{Discussion}

In this section, Journal of Destination Marketing \& Management has the highest ranking across the different journals in the area of MAHs based on its number of published articles and their citations. In addition, the publisher Elsevier has the highest number of published articles with 58. Results also demonstrated that the collaboration between Ecuador and Spain accomplished the highest ranking, such that the strength link was estimated to be equal to 3 . Moreover, the highest repetitive keywords were indicators with 20 times and cultural heritage cities with 19 times. This study will help researchers to understand the current trends, progress, methodologies and challenges related to maintenance of heritage sites. Also, it provides a critical and synthesized evaluation of the current research studies in domain of maintenance approaches of heritage sites.

\section{Conclusion}

53 journal articles were surveyed in this study to provide an overview of the maintenance of heritage sites. Results showed that the highest collaboration research was between Spain and Ecuador has 3 link of strength while Mexico and Spain has 2 link of strength in number of publication related to MAHs. This was proven by comparing the most publishing countries (Spain, Italy, and the UK) with their percentage of research contributions in the examined articles pool. The analysis of countries shows that nations around the world should have stronger collaborations for the research conducted in heritage as heritage belongs to all humanity. An assessment of the quality of the assessed publications was conducted and showed that Spain has a high quality of publications due to the high average number of citations per publication. Also, the highest researcher in terms of number of publication was MartinezPerez with 10 papers and scoring of $3.56 \%$. To sum up, maintenance approaches were surveyed and identified along with their preferred setup and how are they applied. Popular condition assessment technologies were also identified and defined. Their advantages and disadvantages were listed to provide a quick overview of the state of the art in the field. Furthermore, real-life referred research examples were provided for each technique to establish direction for researchers who intend to investigate a specific technique further.

\section{References:}

[1] UNESCO U (2005) Decade of education for sustainable development: 2005-2014.

[2] Leask A, Fyall A (2006) Managing world heritage sites. Routledge

[3] Vecco M (2010) A definition of cultural heritage: From the tangible to the intangible. J Cult Herit 11:321-324

[4] Penttilä H, Rajala M, Freese S (2007) Building information modelling of modern historic buildings.

[5] Tomaževič M, Lutman M (2007) Heritage masonry buildings in urban settlements and the requirements of Eurocodes: Experience of Slovenia. Int J Archit Herit 1:108-130

[6] Dann N, Cantell T (2007) Maintenance in conservation. Underst Hist Build Conserv 185-198

[7] Forsyth M (2007) Historic Building Conservation. Wiley Online Library

[8] Idrus A, Khamidi F, Sodangi M (2010) Maintenance management framework for conservation of heritage buildings in Malaysia. Mod Appl Sci 4:66 
[9] Kerr JS (2013) Conservation Plan, the 7th edition: A guide to the preparation of conservation plans for places of European cultural significance.

[10] Al-Sakkaf, A., Ahmed, R., \& Afifi, M. (2021). Risk Assessment Model for Heritage Buildings: Case Study of Yemen. Journal of Architectural Engineering, 27(2), 04021009.

[11] Harden, A., \& Thomas, J. (2010). Mixed methods and systematic reviews: Examples and emerging issues. Sage handbook of mixed methods in social \& behavioral research, 2, 749-774.

[12] Heyvaert, M., Maes, B., \& Onghena, P. (2013). Mixed methods research synthesis: definition, framework, and potential. Quality \& Quantity, 47(2), 659-676.

[13] Rahmani, A. M., Gia, T. N., Negash, B., Anzanpour, A., Azimi, I., Jiang, M., \& Liljeberg, P. (2018). Exploiting smart eHealth gateways at the edge of healthcare Internet-of-Things: A fog computing approach. Future Generation Computer Systems, 78, 641-658.

[14] Poulios I (2010) Moving beyond a values-based approach to heritage conservation. Conserv Manag Archaeol Sites 12:170-185

[15] Degloorkar NK, Pancharathi RK (2020) Characterization of ancient mortar for sustainability of an 800 year old heritage site in India. Mater Today Proc

[16] Corradi M, Osofero AI, Borri A (2019) Repair and reinforcement of historic timber structures with stainless steel-A review. Metals (Basel) 9:106

[17] Al-Kheder S, Al-Shawabkeh Y, Haala N (2009) Developing a documentation system for desert palaces in Jordan using 3D laser scanning and digital photogrammetry. J Archaeol Sci 36:537-546

[18] Remondino F, Rizzi A (2010) Realitybased 3D documentation of natural and cultural heritage sites-techniques, problems, and examples. Appl Geomatics 2:85-100

[19] Dore C, Murphy M (2012) Integration of Historic Building Information Modeling (HBIM) and 3D GIS for recording and managing cultural heritage sites. In: 2012 18th International Conference on Virtual Systems and Multimedia. pp 369-376

[20] Jahanshahi MR, Masri SF, Padgett CW, Sukhatme GS (2013) An innovative methodology for detection and quantification of cracks through incorporation of depth perception. Mach Vis Appl 24:227-241

[21] Galantucci RA, Fatiguso F (2019) Advanced damage detection techniques in historical buildings using digital photogrammetry and 3D surface anlysis. J Cult Herit 36:51-62

[22] Filho HJ, dos Santos Salazar RF, da Rosa Capri M, et al (2011) State-of-the-Art and Trends in Atomic Absorption

[23] Pinheiro AC, Mesquita N, Trovão J, et al (2019) Limestone biodeterioration: A review on the Portuguese cultural heritage scenario. J Cult Herit 36:275-285

[24] Comite V, De Buergo MÁ, Barca D, et al (2017) Damage monitoring on carbonate stones: Field exposure tests contributing to pollution impact evaluation in two Italian sites. Constr Build Mater 152:907-922

[25] Collado-Montero FJ, Calero-Castillo AI, Melgosa M, Medina VJ (2019) Colorimetric Evaluation of Pictorial Coatings in Conservation of Plasterworks from the Islamic Tradition. Stud Conserv 64:90-100

[26] Arndt RW (2010) Square pulse thermography in frequency domain as adaptation of pulsed phase thermography for qualitative and quantitative applications in cultural heritage and civil engineering. Infrared Phys Technol 53:246-253

[27] De Capua C, Morello R, Jablonski I (2018) Active and eddy current pulsed thermography to detect surface crack and defect in historical and archaeological discoveries. Measurement 116:676-684

[28] Castillo RV, Pérez-Lara MA, RiveraMuñoz E, et al (2012) Thermal imaging as a non destructive testing implemented in heritage conservation. J Geogr Geol 4:102113

[29] Fierascu I, Fierascu RC, Fotea P (2019) Application of Fourier-Transform Infrared Spectroscopy (FTIR) for the Study of Cultural Heritage Artifacts. In: VR Technologies in Cultural Heritage: First 
International Conference, VRTCH 2018,

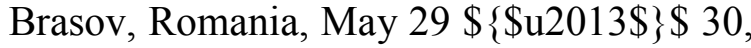
2018, Revised Selected Papers. p 3

[30] Rosi F, Cartechini L, Sali D, Miliani C (2019) Recent trends in the application of Fourier Transform Infrared (FT-IR) spectroscopy in Heritage Science: from micro-to non-invasive FT-IR. Phys Sci Rev 4:

[31] Capitani D, Di Tullio V, Proietti N (2012) Nuclear magnetic resonance to characterize and monitor cultural heritage. Prog Nucl Magn Reson Spectrosc 64:29-69

[32] Proietti N, Capitani D, Di Tullio V (2014) Applications of nuclear magnetic resonance sensors to cultural heritage. Sensors 14:6977-6997

[33] Camm GS, Butcher AR, Pirrie D, et al (2003) Secondary mineral phases associated with a historic arsenic calciner identified using automated scanning electron microscopy; a pilot study from Cornwall, UK. Miner Eng 16:1269-1277

[34] Melcher M, Schreiner M (2005) Evaluation procedure for leaching studies on naturally weathered potash-lime-silica glasses with medieval composition by scanning electron microscopy. J Non Cryst Solids 351:1210-1225

[35] Vasiliev AL, Kovalchuk M V, Yatsishina EB (2016) Electron microscopy methods in studies of cultural heritage sites. Crystallogr Reports 61:873-885

[36] Ruedrich J, Knell C, Enseleit J, et al (2013) Stability assessment of marble statuaries of the Schlossbrücke (Berlin, Germany) based on rock strength measurements and ultrasonic wave velocities. Environ earth Sci 69:1451-1469

[37] Akoglu KG, Kotoula E, Simon S (2020) Combined use of ultrasonic pulse velocity (UPV) testing and digital technologies: A model for long-term condition monitoring memorials in historic Grove Street Cemetery, New Haven. J Cult Herit 41:8495

[38] Rucka M, Wojtczak E, Zielińska M (2020) Integrated Application of GPR and Ultrasonic Testing in the Diagnostics of a Historical Floor. Materials (Basel) 13:2547
[39] Niu B, Hong S, Yuan J, et al (2014) Global trends in sediment-related research in earth science during 1992--2011: a bibliometric analysis. Scientometrics 98:511-529

[40] Wang H, He Q, Liu X, et al (2012) Global urbanization research from 1991 to 2009: A systematic research review. Landsc Urban Plan 104:299-309

[41] Little TD (1997) Mean and covariance structures (MACS) analyses of cross-cultural data: Practical and theoretical issues. Multivariate Behav Res 32:53-76

[42] Roberts JA, Hann I-H, Slaughter SA (2006) Understanding the motivations, participation, and performance of open source software developers: A longitudinal study of the Apache projects. Manage Sci 52:984-999

[43] Vincenzo Barrile, Antonino Fotia, Ernesto Bernardo, Gabriele Candela, Geomatics Techniques for Submerged Heritage: A Mobile App for Tourism, WSEAS Transactions on Environment and Development, ISSN / E-ISSN: 1790-5079 / 2224-3496, Volume 16, 2020, Art. \#60, pp. 586-597.

[44] Rui Alexandre Castanho, Gualter Couto, Pedro Pimentel, C?lia Carvalho, ?urea Sousa, Jacinto Garrido Velarde, Assessing the Impacts of Public Policies Over Tourism in Azores Islands. A Research based on Tourists and Residents Perceptions, WSEAS Transactions on Environment and Development, ISSN / E-ISSN: 1790-5079 / 2224-3496, Volume 16, 2020, Art. \#77, pp. 744-753.

[45] UNESCO (2020) UNESCO 2020. In: Number World Herit. Prop. inscribed by each State Party. https://whc.unesco.org/en/list/stat/.

Accessed 19 May 2021

[46] Howard M (2006) Best practices maintenance plan for school buildings. Idaho State Dep Educ

[47] Al-Sakkaf, A., Zayed, T., Bagchi, A., Mahmoud, S., \& Pickup, D. (2020). Development of a sustainability rating tool for heritage buildings: future implications. Smart and Sustainable Built 
Environment.

[48] Legat V, Jurča V (2004) Maintenance management using quality approach. Tech Fac Dep Qual Dependebility Mach Prag

[49] Levitt J (2009) The handbook of maintenance management. Industrial Press Inc.

[50] Lam KC (2001) Quality assurance system for quality building services maintenance

[51] Iwarere HT, Lawal KO (2011) Performance measures of maintenance of public facilities in Nigeria. Res J Bus Manag 5:16-25

[52] Ali M, Mohamad WMNBW (2009) Audit assessment of the facilities maintenance management in a public hospital in Malaysia. J Facil Manag

[53] Cholasuke C, Bhardwa R, Antony J (2004) The status of maintenance management in UK manufacturing organisations: results from a pilot survey. $\mathrm{J}$ Qual Maint Eng

[54] Shamsuddin A, Masjuki H, Zahari T, others (2004) State of implementation of TPM in SMIs: a survey study in Malaysia. J Qual Maint Eng 10:93-106

[55] Alsyouf I (2009) Maintenance practices in Swedish industries: Survey results. Int J Prod Econ 121:212-223

[56] Al-Sakkaf, A., Zayed, T., \& Bagchi, A. (2020). A sustainability based framework for evaluating the heritage buildings. International Journal of Energy Optimization and Engineering (IJEOE), 9(2), 49-73.

[57] López FJ, Lerones PM, Llamas J, et al (2018) A review of heritage building information modeling (H-BIM). Multimodal Technol Interact 2:21

\section{Contribution of individual authors to the creation of a scientific article (ghostwriting policy)}

\begin{abstract}
Abobakr Al-Sakkaf analyzed the findings and the results of the models and aided in writing the article. Samer El-Zahab developed the methodology and concept and aided in writing the article. Eslam Mohammed Abdelkader aided in developing the methodology and concept and writing the article. Ghasan Alfalah aided in analyzing the models and writing the article.
\end{abstract}

\section{Creative Commons Attribution License 4.0} (Attribution 4.0 International, CC BY 4.0)

This article is published under the terms of the Creative Commons Attribution License 4.0

https://creativecommons.org/licenses/by/4.0/deed.en US 